\title{
The Direct and Major Operational Relevance of Social Assessments
}

\author{
Jonathan C. Brown
}

Do international development agencies listen to the people they are trying to help? And if they listen, do they really hear? And if they hear, do they understand and follow up in ways that affect what we do?

In the mid-1990s development agencies are questioned by skeptics who contend that even if institutions like the World Bank want to listen to the people, they lack the means to do so, being trained in remote oases of learning in professions distant from what constitutes reality at the grassroots level of developing societies.

Indeed, development agencies face a major challenge in defining their roles and in mobilizing support at a time when the themes of the day are fiscal restraint (less money) and more discipline (fewer people doing more).

Some development agencies are responding to such criticisms by strengthening the quality of their technical, financial, economic, and environmental work. And they are reaching out to the people they are trying to help — the ultimate "clients" or main "stakeholders"- to work with, rather than for them.

\footnotetext{
This article was written in 1996 by Jonathan Brown, the chief of the operational division tasked to provide policy advice for investment lending for infrastructure, energy, and the environment to the Bank and to the new states emerging from the collapse of the Soviet Union (the Russian Federation, Azerbaijan, Kazakhstan, Kyrgyz Republic, Tajikistan, Turkmenistan, and Uzbekistan). Jonathan Brown was not what is usually understood by the term "social specialist," as he was highly trained in in economics with degrees from Yale and Harvard Business School. He was strongly supportive and creative in the use of analytical and social tools such as social assessments for projects, an alternative concept for "sociological analysis" required by the Bank's "project appraisal" OMS 2.20. Most of the "social assessment" studies to which this article refers were carried out by the Bank's Social and Environmental Division in the Central Asian countries headed at the time by Ayse Kudat, a Bank sociologist with vast international experience. This article appeared first in 1997 in the book titled Social Assessments for Better Development: Case Studies in Russia and Central Asia, edited by Ayse Kudat and Michael M. Cernea, published in the ESD Vice Presidency monograph series as a "work in progress for public discussion."
} 
In the private sector this is called marketing, demand assessment, or testing consumer preferences. No private company would operate or launch a product without demand assessment and marketing. And even then, the number of bankruptcies and failed products testifies to the difficulty of successful market gauging. Among other international development agencies, such as the multilateral development banks like ADB, IDB, and AfDB, stake-holder consultation at the grassroots level is still an innovation yet to be accepted and insti-tutionalized. In the past, failure to consult ade-quately with stakeholders may have contributed to failure of project operations, but unlike private sector firms, the international development agencies themselves were not put at risk when their products failed. And to be fair, governments and their public servants were often as unwilling or as unprepared to consult with stakeholders as the international develop-ment agencies and their civil servants. While the private sector has spent much of the twentieth century expanding and deepening their "marketing procedures" so that marketing became an acceptable "profession," stakeholder consultation in development agen-cies doesn't yet have the reputation of a profes-sion - a status that economists, technicians, and financial analysts have achieved and toward which environmentalists are still struggling. Rather, stakeholder consultation and social analysis (separate from economic or technical analysis) are mistakenly seen as something anyone can do. This paper illustrates the contribution of social assessment-one mechanism for stake-holder consultation - used by the World Bank. It has improved the substance and process of pol-icy reform and investment projects in develop-ing countries and economies in transition. The case studies presented result from the work of the social scientist group in the Europe and Central Asia region of the Bank and cover the period of 3 years when social assessments were introduced in that region.

While it is accepted in principle that consult-ing the people-arguably the most important stakeholders in the development or transition process-should be systematically done by the World Bank, this consultation process is, in fact, rarely done. When it is done, it is often done superficially. And when it is done well, the findings are not always followed up. This has happened in part because consultation is rarely the result of a structured process performed by specialized professionals trained in the social sciences. This situation has persisted because there have been too few examples of successful social analysis to serve as guides. Therefore, many World Bank staff have not been prepared to spend intellectual and monetary resources on social assessments and local consultation.

The consultation process can be narrow or broad. At its most narrow-as often occurred in the past-a World Bank staff member talks with officials in a country and on this basis alone pol-icy dialogue or an investment project moves for-ward. At its broadest reach, the consultation process involves a wide range of stakeholders, including those people, groups, and institutions directly affected by the policy reform or invest-ment project.

The narrow consultation is easier-not much more effort is required than looking in a mirror. The broad consultation requires more time and resources and a professional approach. The social assessment-a systematic, sociologically and methodologically guided process of learning about stakeholders-is an important 
mech-anism for involving a full range of stakeholders. Social assessment is not the whole participation process but one input. For social assessments to gain credibility among World Bank staff and government officials-who are economists, financial analysts, technicians from many sec-tors, and even generalists-it is important to demonstrate that these "strange" products that result from the work of non-economic social sci-entists really do facilitate the process and improve the substance of the World Bank's basic products: policy reform and investment projects.

This chapter summarizes the relevance of social assessments to policy reform, investment projects, and lending for emergencies from the viewpoint of a division chief who is responsible for preparing, appraising, and supervising development projects and who is not a social sci-entist himself. It suggests reasons why social assessments have been more readily accepted in theory (by World Bank staff and governments) than in practice. Finally, the chapter will suggest institutional mechanisms to facilitate the accep-tance of social assessments, either through per-suasion-the basic thrust of this book-or through institutional norms within the domain of good management and leadership.

\section{Social Assessments for Preparing Policy Reform}

It is believed that improving the welfare of peo-ple in developing and transition economies requires institutions and policies that encourage economic growth and allow for the sustainable development of essential services. Part of the policy theology is that reform is usually unpleas-ant and has to be forced on people by govern-ments, resulting in conflict. People are seen as part of the problem rather than as part of the solution.

Seeing people as the enemy of policy reform is nowhere more evident than in the debate over cost recovery, or who will pay for essential goods and services. The reform theology assumes that people will resist higher tariffs. But is it true that higher tariffs mean higher real costs for people in all cases? And even if this is true, will people object? Social assessments play a critical role in this debate. Their findings, as indi-cated in this book, have shown that higher tar-iffs can lead to lower real costs and that higher prices will be accepted by consumers if there is a credible expectation of improved services. Social assessments can give courage to govern-ments facing the need for cost recovery meas-ures by allowing the people to be supporters of reform.

During the preparation of the Baku (Azerbaijan) Water Supply Rehabilitation Project in 1994, water company officials and the World Bank team concluded that higher tariffs were essential to provide the financial resources necessary to put the Baku water company on a sound financial footing. However, discussions with the government over raising tariffs quickly became emotional. Government officials raised the specter of public riots, while the water company and World Bank team offered the gloomy vision of corporate bankruptcy. 
The stalemate was broken as a result of the social assessment done as part of early project preparation. The social assessment found that although the public water supply service was inadequate throughout Baku, the low-income segment of the city's population suffered the most from the water situation. On average, households spent about seventeen times more on alternative water supplies than on their monthly water bills. The poor spent $7 \%$ of their income on coping strategies while wealth-ier citizens spent only $2 \%$. The social assessment also showed that householders would be willing to pay substantially more than their current monthly water charge for better public water service. The poorest elements of the population were prepared to pay $6 \%$ of their income, a slight decrease from their current payments for coping mechanisms.

The water company and World Bank team found that a tariff level of about $4 \%$ of income for the poorest population segments was sufficient for the company's financial objectives. The government could argue that while this was an increase in tariffs, it was actually a reduction from the $7 \%$ this group was currently pay-ing for alternative water supply.

The social assessment was accepted in Azerbaijan because it was done by a team of World Bank and Azeri social scientists and was based on detailed surveys done professionally and presented in a user-friendly way, including public fora which were televised.

The role of social assessment in facilitating discussions of cost recovery was even more dra-matic in Turkmenistan during the early prepa-ration of the Urban Transport Project. Carried out in February 1995, before issues of cost recov-ery were even discussed with the government, the social assessment revealed a situation in Ashgabat of poor service in public transport and of tariffs so low that there was no coin small enough for a passenger to pay a single-ticket fare. The result was an unsustainable and dete-riorating public transport system. The poorest quarter of households were compelled to spend $12.8 \%$ of their income on various mecha-nisms for coping with the lack of public trans-port or to make "extra" payments for using public transport when it was available.

The social assessment also revealed that $94 \%$ of public transport users would accept a $200 \%$ increase in tariffs if there would be real improvement in service. Tariff increases were immediately put into operation. The quick improvement in public transport service resulted in the poorest households paying higher fares but incurring lower real costs for transport when compared to the cost of their previous coping mechanisms. Raising tariffs lowered the real cost of transport and cost recov-ery was never an emotional issue during project preparation.

Turkmenistan's Urban Transport Project is the World Bank's first investment operation in this new member country. As part of project preparation the government has issued a "Declaration on Urban Transport Policy" an Action Plan setting out the policy objectives to be implemented during the project's lifetime, and an Operations Improvement Plan to sup-plement the list of improvements already imple-mented. It is unusual for a policy reform package to be prepared by a government before World Bank financing has been negotiated, espe-cially for a new member of the World Bank. There is no absolute proof, but one might sug-gest that the bank's social 
assessment turned urban transport consumers into allies of reform. It also emboldened the government, which was highly satisfied with the Bank's social assessment study, to take steps towards policy change.

Social assessments can be particularly helpful where cost recovery's impact on different popu-lation groups is more complicated. In the Kyrgyz Republic the World Bank provided a \$20 million International Development Association (IDA) credit in June 1996 to fund a Power and District Heating Rehabilitation Project. Cost recovery was a contentious -issue for the government, since social considerations and its policy of pro-moting domestic power use were the main rea-sons for keeping power and heat tariffs artificially low and the structure biased towards household consumers. The result was an unsus-tainable deterioration in the financial situation of the energy utility, inefficient and uneconomic energy consumption, and inequitable prices. A social assessment of proposed tariff increases was carried out during project preparation. The findings of the assessment indicated that the proposed tariff increase for electricity was feasible, while the increase for district heating was feasible only if a social safety net was introduced to protect low-income households. Households without access to district heating, and therefore relying on natural gas and coal for heat, also needed protection. The impact of the tariff increase on electricity could be mitigated by maintaining a reduced subsistence tariff for resi-dential consumers. The outcome was that higher tariffs were introduced where they were affordable, with a social safety net designed for those groups for which it had been demonstrated that the financial burden would be too great.

The important contribution of the social assessment was to provide a framework of facts, figures, and predictable outcomes that took the subjectivity and ideology out of the cost recov-ery debate.

The contribution of social assessments to policy reform can be broadened to encompass entire sectors engaging in major restructuring where the World Bank is supporting the reform program through a sector adjustment loan (SECAL), as the Russian coal case illustrates.

In June 1996 the World Bank approved a \$500 million loan for Coal Sector Adjustment in Russia in support of the government's program to reduce the adverse impact of the coal sector on the federal budget by making possible the decrease and eventual elimination of sector sub-sidies, which in 1993 amounted to 1\% of GDP; promote the long-term sustainability of the coal sector through the establishment of a com-petitive, commercial industry; support a restructuring program to reduce the size of the industry while increasing its efficiency; and cushion the socioeconomic impacts of the restructuring on coal miners, their families, and affected communities. The SECAL was accompanied by a $\$ 25$ million loan for a Coal Sector Restructuring Implementation Assistance Project, which included:

- Support for stakeholders' participatory activities at the national, regional, and local level for government, coal industry, and non-governmental institutions

- Social programs to be implemented by local governments, nongovernmental and community-based organizations with continuous social assessment, and social impact monitoring of the coal reform program 
- Improvements of the management of government subsidies to the coal sector to enhance transparency and financial accountability and to ensure that target groups received the level of subsidies for the purposes intended

- Assistance for commercialization and demonopolization of coal companies, environmental management associated with the coal industry, development of procedures for closing unprofitable mines, and for operation of the government's coal reform agency in the Ministry of Economy.

The social assessment carried out as part of the SECAL's preparation had a profound impact on the coal reform program by:

- Demonstrating (unexpectedly) that non-miners in coal regions were the largest group affected adversely by the coal reform program. In response, a major part of coal sector subsidies was reoriented to coal communities for the population at large rather than to coal companies for coal miners who had been a privileged economic group. In addition new mechanisms were devised to make the purpose, beneficiaries, and the distribution channels for subsidies more transparent and able to be monitored.

- Revealing that human settlements in the coal region have diverse characteristics with respect to demographic structure, income level, and labor force. This would appear to be self-evident but much of the reform agenda treated the coal sector as a monolith. The social assessment persuaded the government to recognize the local nature of many of the problems and of possible solutions for the coal sector.

- Demonstrating that the transfer of social assets from coal companies to local governments - an important objective of the coal reform program — was having adverse effects on local communities that were not previously anticipated. In response, coal subsidies for social assets were redirect from coal companies to coal communities.

- Showing that miners and non-miners had low trust in the government, in the coal industry, and in outside agencies such as the World Bank, but would trust a new institution representing of a broad range of stakeholders. The interagency Coal Commission and the Association of Coal Mining Cities, new institutions with broad stakeholder representation, became the vehicles by which many decisions were made. In addition pilot programs were created to channel loan funds for the first time in Russia to nongovernmental and community-based organizations, as well as to labor unions.

- Suggesting that measures to enhance workers' ability to move freely in search of alternative employment were seen by many coal miners facing job loss as more relevant than expensive job creation schemes whose funding and efficiency were questionable.

Difficult negotiations between the groups in Russia pushing for reform and those advocating the status quo-with control over nearly $\$ 2$ billion in annual subsidies at stake-were affected by what the social assessment revealed about the coal mining regions and peoples' concerns, especially about the subsidy system and the pro-cedures for closing mines. At one point in the negotiations over the subsidy system, 
the sup-porters of the status quo produced an elaborate justification for keeping the existing system. The advocates of reform pointed to the results of the social assessment this way: those who were sup-posed to benefit from subsidies had no trust in the existing system. The findings showed that it was not the reformers alone or an outside insti-tution like the World Bank proposing and supporting change, but the people themselves. The subsidy system was changed.

In addition, donor support, particularly from the World Bank, was facilitated because Russia could demonstrate that its coal sector reform program was cushioning the impact of reform on the most affected people, as the people them-selves thought relevant and appropriate when they spoke through the social assessmenttheir vehicle for stakeholder consultation. Experience from around the world has shown that reform of coal sectors is difficult, costly, and takes many years, if not decades, to happen. The social assessment gave World Bank staff more confidence that Russia's coal sector reform program was based on realities in the coal mining areas and responded to the real needs of people. The Implementation Assistance Project's funding of social monitoring ensured that the process of social assessment and stakeholder participation would continue to be part of the future reform agenda for coal in Russia.

\section{Social Assessments Are Essential for the Bank's Sector Analysis Work}

Sector work in the World Bank is designed to identify systematically the challenges, con-straints, and options for a country in a specific sector, based on that country's own situation-such as population, resources, and needs - and considering relevant worldwide factors. Sector work sets the framework for the Bank's invest-ment lending and policy dialogue in a sector as well as its identification of specific investment opportunities.

Given the scope and importance of compre-hensive sector studies, it would appear that social assessments should be key building blocks on which sector work is founded. Yet this has not been the case in the countries covered by this book, except perhaps for the Bank's poverty assessment studies. The explanation for this gap is the need for World Bank sector work to con-centrate on macroeconomic analysis for new Bank members and on sector issues for which reform options have been explored in other parts of the world and are thought to be trans-ferable to the countries of the former Soviet Union. Also, these countries' desire to borrow quickly for investment projects has meant that sector work and project preparation have in many cases been merged, rather than carried out in sequence. Still, sector reform is deeply country specific, and would benefit greatly from social assessment at the sector level.

The first draft of the Russia coal sector report, for instance, covered the coal industry as one national industry to be analyzed. The Russians requested the World 
Bank team to do a second draft, assessing the industry coal basin by coal basin. The final report was a much more relevant document that served as an important basis for preparing the Russia Coal Social Adjustment loan. Thus a social assessment at the sector level proved to be, in this case, very useful for designing a major, sector-wide restructuring intervention. It is likely that this is true for all or most Bank and borrower programs, and that the use of social analysis in sector-wide studies and programs could be considerably expanded, both within the Bank and in other institutions.

When identifying constraints and reform options, sector work should investigate the social processes and factors that determine the current situation in the sector as well as the framework for realistic reform. As such, social assessment could have important contributions in:

- Identifying key sector stakeholders and proposing a framework for their participations as actors in sector reform

- Evaluating the impact of reform options on stakeholders, especially to gain their support where possible and to understand their opposition when it occurs

- Designing measures to mitigate adverse effects of sector reform proposals

- Identifying cost-effective interventions that could be undertaken immediately, the "win-win" actions that facilitate the implementation of sector reform in its early stage

- Determining whether a sector is appropriate for Bank investment operations given the Bank's social development and poverty reduction objectives, including the most appropriate target groups and geographic areas where these objectives can best be achieved.

The social assessment in sector reviews is a more systematic process of stakeholder consultation, especially in countries of the former Soviet Union, where the traditional institutions of civil society such as nongovernmental orga-nizations are not as representative of population viewpoints as they are in other parts of the world.

Utilizing of social assessment in sector reviews would go far in defining the social development agenda so that a social assessment would not have to be done in great depth for each investment operation in the sector.

\section{Social Assessments and Investment Lending}

The social assessments that our division has supported and used have had a profound effect on the focus and shape of our investment pro-jects in countries of the former Soviet Union. As a result, these investment projects are more appropriate for the people being helped, more efficient and financially viable, involve the peo-ple in ways that reduce investment costs and improve operational performance, and are environmentally more sustainable. This may seem an ambitious contention, but if true, it implies that social assessments can make as great a con-tribution to World Bank investment lending as the traditional economic, financial, technical, and 
environmental tools for evaluating projects. Consider, for instance, the Baku (Azerbaijan) Water Supply Rehabilitation Project for which a \$61 million IDA credit was approved in June 1995. This project was originally conceived as the provision of pumping stations and spare parts so that the traditional water company operations could be "restarted." As a result of the social assessment, however, the focus of the project shifted substantially towards involving the consumers in the investment project.

The social assessment revealed the high level of water losses caused by leaks in households and in the distribution system. This resulted in the project's budgeting for a community-based repair and maintenance system for 180,000 households, as well as for a major network repair program. The social assessment also illustrated the need for a metering and billing pro-gram for households and industries as a means for improving the water company's finances and for promoting water conservation. A consumer outreach and awareness-raising program was designed to provide information on reducing water losses, to build public awareness about the scarcity of water and the need for conserva-tion, to show the importance of community par-ticipation in leakage repair programs, and to explain the need to pay for water and the advan-tages of metering for improved cost recovery.

The social assessment also showed that the water company had little knowledge about the preferences of its customers. Therefore, the project included establishing a consumer relations unit within the water company to deal with con-sumers as partners.

In Kazakhstan in 1995 the government and the World Bank initiated a detailed preparation for a Water Supply, Sanitation, and Health Project in the Aralsk and Kazalinsk regions, the parts of the country most affected by the deterioration of living conditions resulting from the Aral Sea shrinkage. A social assessment was carried out that showed that people's concern about water was in fourth place, behind income to buy food, cooking fuel shortages, and unpaid wages. As a result, project preparation was stopped, redirected, and begun with a wider focus on peoples' concerns, especially the contribution of water to economic activities such as gardening and raising livestock. Rather than start with a full scale investment project, the government and the World Bank decided to fund a small pilot project to test project design and implementation capacity. Thus, the major contribution of the social assessment in Kazakhstan was in reorienting project preparation before it had gone too far in a direction that did not respond to peoples' needs. In Turkmenistan the initial orientation of the Urban Transport Project was toward the provision of new buses and spares to raise the level of service. The social assessment done during project identification revealed a system in chaos, with $90 \%$ of users dissatisfied with the service, which was practically non-existent during the evening rush hour. The key problems were the behavior of drivers and the poor finances of the bus company. The social assessment identified a number of operational improvements and potential solutions, including:

- Substantially raising bus drivers' salaries thus reducing their incentive to exploit the public in order to supplement their incomes. At the same time transport 
supervisors were designated to ride on buses to monitor driver behavior, and fare collectors were added to buses. This "carrot and stick" approach to the key problem of driver behavior resulted in a marked improvement in driver performance and hence in better service to the public.

- Increasing the nominal fare by $200 \%$ and making other improvements in ticket availability. This improved bus company finances enough to keep more buses in service.

As a result of these reforms more buses were available for longer periods of time, allowing an improvement in bus scheduling, and satisfying a key complaint of consumers. Internal management and personnel policies were also improved.

In this way, the social assessment made possible real improvements in urban transport service more than 18 months before World Bank investment funds were scheduled to become available.

The Turkmenistan social assessment revealed that the findings of social assessments cannot always be acted on automatically and that they, in turn, must be subject to the other usual analytical criteria for investment lending: economic, financial, technical, and environmental. That social assessment showed, for instance, that consumers expressed strong preference for having a seat in public transport vehicles during rush hour. If acted on uncritically, this priority would have resulted in overinvestment, since few urban transport systems can afford to satisfy this demand. Furthermore, the social assessment's survey by city zones reported the need to improve the road systems in parts of the city. Although also a legitimate concern this need was not within the financial possibilities of the Bank-funded project.

Perhaps the most extensive use of social assessment occurred during the preparation of the Uzbekistan Water Supply, Sanitation, and Health Project. As part of an extensive stakeholder consultation process on the project design, five distinct social assessments on different aspects of the project were carried out. One of these covered Karakalpakstan and Khorezm - the two administrative territories most severely affected by Aral Sea Basin conditions-and were very helpful in directing the investments necessary for addressing the environmental and social consequences.

With regard to implementation arrangements, the social assessment and participation process helped convince people to change their view on some design options for the project. In initial meetings, people expressed strong preference for a selfmanaged water supply scheme because they believed that the local water company, Vodokanal, would provide poor service if it managed the plan. However, when the community received information on the advantages, disadvantages, and costs of the various schemes, they agreed with the experts' recommendation to link the community with the main supply pipeline operated by Vodokanal. This community consultation approach was a first experience for Vodokanal. While initially there was a hostile reaction from the community and apprehension from Vodokanal's perspective, the end result has been beneficial for all stakeholders.

The social assessment also changed the technical parameters of a key project including the definition of what is "acceptable" water quality. The government suggested that a water supply project would have to use low-cost investments such 
as shallow wells and handpumps. But the social assessment found that $68 \%$ of households complained of the salty taste of their main water supply. It was then decided to complement the social assessment with a salinity taste-tolerance survey. This survey found that the local population would tolerate salinity up to $2000 \mathrm{mg} / \mathrm{l}$, and twice higher than Uzbekistan's own national standard of $1000 \mathrm{mg} / \mathrm{l}$.

This finding had important cost-savings implications for the project: given resource scarcity, the project can make smaller investments in water quality to meet the $2000 \mathrm{mg} / \mathrm{l}$ tolerance level rather than the $1000 \mathrm{mg} / \mathrm{l}$ national standard. On the other hand, the survey demonstrated that shallow wells and handpumps, supplying water with salinity levels between 5000 and $7000 \mathrm{mg} / \mathrm{l} \mathrm{might} \mathrm{appear} \mathrm{to} \mathrm{allow} \mathrm{an}$ acceptable investment pattern. But this appearance is deceptive from the consumer's viewpoint, because the water produced would be undrinkable.

The social assessment and the local consultation process also suggested that it was possible to test a lower water consumption design standard, which would permit reducing investments and operating costs of water distribution networks. The current design norm of 3501 per person per day has been reduced to 1501 per person per day, a change made primarily for financial reasons. This change might well have been rejected as socially unconscionable had the information supplied by consultations and social assessment not been available.

Finally, the social assessment showed that people's highest priority was access to income-generating activities. This finding led to the introduction of several pilot schemes implemented by the government and financed by the donor com-munity. The project design adopted a labor-inten-sive approach to water supply and sewerage investments in order to maximize local employ-ment opportunities. Proponents of this approach, however, will still have to battle it out with the external commercial interests who are proposing capital-intensive approaches, but at least there is evidence of support from the affected people.

The social assessment for Uzbekistan pro-vided me-and my colleagues on the project's operational and financial sides-with valuable information, otherwise unavailable, about how much water consumers in rural areas would be prepared to use at various price levels. We also decided that the project would include a pilot demonstration of a water metering system servicing small groups of households organized as water user associations. This will test the benefits of a system that charges consumers for the actual amount of water consumed.

\section{Social Assessments for Emergency and Post-conflict Lending}

Since its establishment after the Second World War the World Bank has had the special role of assisting governments with programs to recover from natural and human-caused disasters and civil strife. Project preparation after floods and humancaused disasters (such as oil spills) often has to be telescoped and done under extreme time pressure as emergency interventions. There is a tendency to conclude that there is "no time to consult" with the affected people. In addition, it is suggested 
that the relief agencies, rather than the World Bank, are the ones that should consult with stakeholders, since choice of relief services will have an immediate effect on stakeholders, in contrast to longer-term reconstruc-tion activities funded by the World Bank.

In reality, however, because of implementation constraints and lack of sufficient money from domestic resources and the donor community, it is common that the reconstruction efforts cannot rebuild completely what has been lost, at least not in the near and medium term. Consequently, consultation of stakeholders about what should be reconstructed, and in what order, is enormously relevant, especially since commercial and political interests often claim that heavy infrastructure reconstruction is more important than social or light infrastruc-ture reconstruction. We have learned that social assessments can be done quickly with results that facilitate decision-making and choices about what needs to be reconstructed and to what standards.

In 1994 the World Bank helped the govern-ment of Tajikistan prepare a preliminary pro-gram of reconstruction following severe floods and a pause in the civil strife. The mandate given to the Bank's team emphasized physical and commercial reconstruction, due to the desperate economic situation of the country, rather than other areas such as shelter, for which temporary measures were thought to be adequate. Yet the social assessment—in this case more traditionally ethnographic, without detailed sample surveys-brought to our attention that shelter in Tajik society was more than housing-it was also the nucleus and location for various economic activ-ities of the extended family. Therefore, the recon-struction program we eventually proposed gave more prominence to housing as filling also the functions of a basic eco-nomic unit, much more than it would have had if we consid-ered housing only as shelter.

In 1994 Tajikistan was a new member of the World Bank, and its local institutions, including community organizations, were unfamiliar to the international community. The social assess-ment raised the possibility of mobilizing com-munity capital based on what already existed from the communist era or was embedded in traditional structures. When the civil strife less-ened, and it became clear that there would be few external resources available for reconstruc-tion, social assessments were continued in Tajikistan. These surveys revealed what people felt were the highest priorities to be delivered through efficient existing channels such as local and international nongovernmental organiza-tions, in the face of an already overburdened public service.

Social assessments can be especially effective for involving stakeholders in selecting priorities when financial resources are limited. In 1996 the Azerbaijan government requested the World Bank and the United Nations Development Programme to help establish the Azerbaijan Resettlement and Reconstruction Agency to assist internally displaced people returning to demilitarized areas surrounding Nagorno--Karabakh. With lasting peace yet to be estab-lished in Nagorno-Karabakh and in view of the international community's preoccupation with reconstruction in Bosnia, it is unlikely that suffi-cient external resources will be available to Azerbaijan in the near term to restore to former levels the full range of 
infrastructure, and social and economic services. The government has instituted a process of social assessments, allowing internally displaced people to help decide how the limited financial resources should be used to improve their lives. It remains to be seen whether the social assessment results will have more impact than the central planning mental-ity of many people in this former Soviet Republic.

Emergency lending poses special demands on social assessments because of the need to move quickly. On January 24, 1994, the govern-ment of the Komi Republic, through the govern-ment of the Russian Federation, requested the World Bank and the European Bank for Reconstruction and Development to provide emergency assistance to deal with the oil spill from a major oil pipeline in the Komi Republic near Usinsk. If not contained, the oil spill threat-ened to flow into the Kolva, Usa, and Pechora Rivers, posing a massive threat to the fragile Arctic climate. The spill, estimated at three times that of the Exxon Valdez on the Pacific Coast of North America, had to be dealt with before the spring floods expected in May and June. Moreover, a spill recovery capacity had to be cre-ated in the river systems in the likely event that the oil could not be fully contained. The leaking pipeline had to be replaced over an $84 \mathrm{~km}$ stretch under difficult construction conditions before further leaks developed and before the spring and summer floods made it impossible to work in the swampy tundra.

The project preparation effort which began the day after the government request and involved social scientists including representa-tives of a local nongovernmental organization-Save the Pechora Foundation. Using interviews and surveys they assessed the priorities perceived by the 7000 people (10\% of the population) living in villages within a $200 \mathrm{~km}$ radius of the affected area.

The social assessment revealed that the high-est priorities were preventing the spill from reaching the river systems and protecting against future pipeline ruptures. A long list of local improvements followed, showing a lack of adequate investment in basic social services over many years. At the top of this list, the peo-ple placed funding for children's vacations and emergency food for livestock.

In its implementation the Oil Spill Recovery and Mitigation Project placed highest priority on preventing the spill from spreading. This was successful. Implementation of the social pro-grams received lower priority and was com-pleted at a slower pace than planned. As often happens the "hardware" got more attention than the "software," but in this instance that emphasis reflected the views of the people most directly affected. Also, the social assessment exercise for the Komi Project did not delay pro-ject preparation or implementation, and it was done at low cost. 


\section{Social Assessments in the World Bank: The Current Situation}

The question inevitably arises: If social assess-ments are as important for World Bank policy work and investment lending as our work has shown, why do we not carry them out system-atically for all projects? And if they are not done very often, what needs to be done to change this?

So far, the Bank's staff members who have championed social assessment-not all of whom are social scientists-have received insuf-ficient support for their efforts.

Some people in the Bank, and in other devel-opment agencies, might contend that social assessments have always been done, have been a part of discussing Bank operations with client countries, and have been included in the work Bank staff did for demon-strating the economic, financial, technical, and environmental justification for projects. This is a retrospective exaggeration, though there has been an improvement in stakeholder consultation in recent years. Such aspects of our social analyses have been done in an ad hoc manner rather than as a result of a systematic, professional approach, as a social assessment should be.

The Participation Sourcebook, published by the World Bank in 1996, states that social assess-ments must be carried out in a project context to do the following:

- Identify key stakeholders and establish an appropriate framework for their participation in the project selection, design, and implementation

- Ensure that project objectives and incentives for change are acceptable to the range of people intended to benefit, and that gender and other social differences are reflected in project design

- Assess the social impact of investment projects and, where adverse impacts are identified, determine how they can be overcome or at least substantially mitigated

- Develop ability at the appropriate level to enable participation, resolve conflict, permit service delivery, and carry out mitigation measures as required.

What this sourcebook recommends about social assessments is what we should have been doing all along - assessing and consulting with those we are trying to help about the best way to help them. It takes humility for the World Bank's management and staff to admit the need to orga-nize differently in order to improve our perfor-mance on consultation. This is what many outside the Bank, and some inside the Bank, have been long saying, and what many more inside the Bank are now admitting.

Good quality, professionally administered social assessments require additional time and financial resources, just when of international donor agencies are being asked to do more with less money and fewer people. The contention that social assessments will save money by improving project performance is probably true. But it is seen by some as a long-term hope better left for tomor-row, especially as Bank staff see their budgets for project preparation being cut. Even fulfilling tra-ditional economic, financial, and technical analy-sis is in doubt. If another 
unfunded mandate is given, yet allowed somehow to remain voluntary, it can hardly be welcomed by those responsible for project preparation in international develop-ment agencies.

If we add the uneven professional output of the social sciences in general, the sometimes weak technical qualifications of some social science staff, and the frequent lack of quality control over social scientists in development agencies, it will be possible to ignore social assessments and yet not feel as though we are contributing any less to solving problems in developing countries or countries in transition. I contend that the poor quality of some of the social science work in the World Bank has much to do with the prejudices of economists, financial analysts, and technicians toward non-economic "social science." When a non-social specialist staff member says that "surveys have been done," meaning by this that thirty-nine people met on the street over several days were kind of asked about a major sector adjustment operation-it should not pass for social science. Client countries and agencies that have profited from decades of perfecting the way the Bank proceeds in doing economic, financial, and technical analysis, do not have far to look for evidence of the sloppiness of what we have often called "spontaneous" social assess-ments. This situation will not change until the international development institutions intro-duce an exacting standard of professionalism for social assessments, and quality control by recognized social scientists and other competent professionals that results in acceptable quality.

The quality of social assessments can be enhanced and costs brought down by the use of local country social scientists. The network of social scientists in Central Asian countries, which the World Bank has helped to establish and which has received generous funding from Switzerland (through the Bank) is an important step and support in this direction.

The World Bank has tried to stimulate the use of participatory approaches in general and social assessments in particular through a positive, voluntary series of measures. These mea-sures have ranged from subsidizing the work of social scientists to helping budget-starved task managers through a special fund, to describing best practices as examples to follow and to publishing the Bank's Participation Sourcebook. This reflects the Bank's early days of environmental work, when it was assumed that attention to environmental concerns would be sufficient to "mainstream" the environment in World Bank policy work and investment operations. Before the recent emphasis in the Bank on what we call "social assessment" as equivalent to the "sociological analysis" or environmental analysis required by the Bank's operational policy on project appraisal, the happenstance initiatives of staff members to discuss with local people did not quite result in the mainstreaming of sound environmental criteria. Often, only when environmental nongovernmental organizations publicized some of the more egregious environmental disasters accom-panying some World Bank loans, did the Bank take a normative or "mandatory" approach. This change included reissuing operational direc-tives for all staff and the creation of environ-mental organizational units in all Bank regional vice presidencies, both for review and for direct environmental work. 
Social assessments and the promotion of participatory approaches seems to be going through the same experience as environmental concerns did earlier. As long as the instructions are only voluntary, and the work unfunded through regular budget allocation, social assessments will often receive the same lip-service that the environment received before structured attention was mandated. Few people will argue that the World Bank is not a better place today due to the seriousness with which it now treats the environment. The same can be said if we treated social assessments with equal seriousness.

The social assessment studies that our division has commissioned were not perfect. But they represent a constructive and useful attempt in some parts of the World Bank to move toward a more professional and relevant process of doing hands-on social analysis and using local social scientists, thus improving the Bank's performance in its new member countries. Social assessments are one of the better means of making the work of international development agencies more effective, more relevant, and genuinely appreciated by the people we are assisting.

Jonathan Brown graduated from Yale in 1966 and the School of Communications at the University of Pennsylvania. After his graduation, he served in the Peace Corps in Chad for 3 years and then returned to the United States to attend the Harvard Business School. He joined the World Bank in 1973. During his 35 year career in the World Bank as a manager of operational units doing lending and policy work he focused geographically on Africa and the countries of the Former Soviet Union, and thematically on energy, infrastructure, health and water supply and sanitation. He reviewed hundreds of projects and sector programs for funding.

Starting as early as in mid-1970s he made sure that people's needs are identified by, and responded to, with the projects of the divisions he headed. He pioneered social assessment and public participation in his work on natural disasters, reconstruction after civil strife, and in policy and project finance. He was involved in assessing the social impacts of numerous projects, particularly in the energy and infrastructure sectors, in preparing mitigation programs dealing with social risks and adverse social impacts, and then in monitoring the implementation of these plans.

After his retirement from the World Bank in 2008, he took on an assignment for 1 year as Director of Operations of the Global Fund against AIDS, TB and Malaria in Geneva to improve the quality of its operations while maintaining high levels of disbursement and to participate in the recruitment of a permanent successor. He helped establish and managed Social Assessment LLC and was the founder of its affiliate, Social Risk Management LLC.

Open Access This chapter is licensed under the terms of the Creative Commons Attribution 4.0 International License (http://creativecommons.org/licenses/by/4.0/), which permits use, sharing, adaptation, distribution and reproduction in any medium or format, as long as you give appropriate credit to the original author(s) and the source, provide a link to the Creative Commons license and indicate if changes were made.

The images or other third party material in this chapter are included in the chapter's Creative Commons license, unless indicated otherwise in a credit line to the material. If material is not included in the chapter's Creative Commons license and your intended use is not permitted by statutory regulation or exceeds the permitted use, you will need to obtain permission directly from the copyright holder.

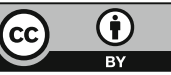

